\title{
ANALISIS FAKTOR YANG BERPENGARUH TERHADAPPROFITABILITASPERUSAHAAN MANUFAKTUR YANG TERDAFTAR PADA INDEKS SAHAM SYARIAH INDONESIA TAHUN 2011-2015
}

\author{
Muhammad Nurul Qomaruddin \\ Mahasiswa Program Studi S1 Ekonomi Islam-Fakultas Ekonomi dan Bisnis-Universitas Airlangga \\ Email: muhammad-nu-q-11@feb.unair.ac.id \\ Ari Prasetyo, S.E, M.Si \\ Departemen Ekonomi Syariah-Fakultas Ekonomi dan Bisnis-Universitas Airlangga \\ Email: ari.prasetyo@feb.unair.ac.id
}

\begin{abstract}
The purpose of this study is to analyze the impact of Days Inventory, Days Receivable, Days Payable, Leverage. Debt to Equity Ratio, Current Ratio on Manufacturing Firms profitability in Indonesian Sharia Stock Index by 2011 until 2015. The problems in this research gap from former Research and the business gap phenomenon from the Manufacturing Firms over period 2011-2015. Therefore a deeper research to observe the problems which influence Return on Assets with reasonable theory

Research variables consisted of six independent variables and 1 dependent variable is profitability (ROA). Data analysis technique to answer research problem and examine research hypothesis using Panel Data Regression Analysis. Data obtained from Indonesian Stock Exchange published via Website realtime, obtained 30 data samples.

Based on the research, known that the effect of Days Payable on Manufacturing Firms profitability partially significant. Meanwhile, other independent variables partially not significant. Otherhand the effect ofall six independent variable simultaneous significant effect on Manufacturing Firms profitability
\end{abstract}

Keywords: Manufacturing Firms, profitability, Days Inventory, Days Receivable, Days Payable, Leverage . Debt to Equity Ratio, and Current Ratio, ROA

\section{PENDAHULUAN}

Industri manufaktur telah lama diharapkan menjadi motor pertumbuhan ekonomi. Namun, hingga menjelang berlakunya Masyarakat Ekonomi ASEAN 2015, daya saing industri manufaktur masih pesimistis menghadapi tantangan tersebut. Di sisi lain, muncul raksasa ekonomi yang berkembang pesat di ASEAN, seperti Malaysia, Thailand, dan Vietnam.

Survei yang dilakuakan McKinsey Global Institute (2012) menyebutkan ada empat sektor potensial yang akan menopang laju perekonomian Indonesia pada masa mendatang, yakni pelayanan konsumen atau jasa, pertanian dan perikanan, sumberdaya alam serta pendidikan.

Memacu daya saing menjadi negara industri maju sangat ditentukan kemampuan dan kapasitas bangsa kita sendiri dalam mengeliminasi berbagai hambatan sekaligus mengoptimalkan potensi sumber daya yang ada.

Menurut Rasyid (2012], ada beberapa faktor yang mendorong Indonesia menjadi negara industri maju. Pertama, tingkat prtumbuhan ekonomi Indonesia dinilai paling stabil di dunia. Kedua, sekitar $90 \%$ pertumbuhan ekonomi nasional berasal dari wilayah diluar Jawa. Ketiga, sekitar $11 \%$ ekspor komoditas berasal dari sektor nonmigas. Keempat, pemakaian sumberdaya sudah berkurang hingga sekitar 7\%. Kelima, sekitar $60 \%$ 
Qomaruddin, et al/ Jurnal Ekonomi Syariah Teori dan Terapan Vol. 5 No. 6 Juni 2018: 448-466; ANALISIS FAKTOR-FAKTOR YANG BERPENGARUH TERHADAP PROFITABILITAS PERUSAHAAN MANUFAKTUR YANG TERDAFTAR PADA ISSI TAHUN 2011-2015

pertumbuhan ekonomi ditopang oleh peningkatan produktivitas. Tujuan akhir yang ingin dicapai perusahaan adalah memperoleh laba maksimal sehingga perusahaan dapat meningkatkan kesejahteraan pemilik, karyawan, serta mutu produk dan melakukan investasi baru.

Oleh karena itu manajemen perusahaan dituntut harus mampu memenuhi target yang telah ditetapkan. Artinya besaran keuntungan haruslah dicapai sesuai dengan yang diharapkan Untuk mengukur keuntungan suatu perusahaan digunakan rasio profitabilitas (Kasmir, 2013 : 196).

Rasio profitabilitas merupakan rasio untuk menilai kemampuan perusahaan untuk mencari keuntungan dan jjuga memberikan ukuran tingkat efektivitas manajemen perusahaan. $\mathrm{Hal}$ ini ditunjukkan oleh laba yang dihasilkan dari penjualan dan investasi. (Kasmir, 2013 : 196).

Setiap aktivitas perusahaan yang menghasilkan laba selalu memerlukan dana, dana yang digunakan untuk melangsungkan kegiatan operasional sehari-hari disebut dengan modal kerja. Modal kerja juga diartikan sebagai investasi yang ditanamkan dalam aktiva lancar seperti: kas, piutang, surat berharga dan persediaan. (Sudana, 2011:189)

Pengelolaan modal kerja yang efektif dapat dilihat dari indikator siklus konversi kasnya yang terdapat dalam tulisan Deloof (2003)Graham dan Nikkinen
(2012) dimana perusahaan yang modal kerjanya efisien mempunyai siklus konversi kas yang semakin pendek. Siklus konversi kas yang pendek mengindikasikan perusahaan mampu menagih dengan cepat piutangnya dan membayar supplier lebih lambat namun tetap mampu menjaga kredibilitasnya. Hal ini akan berdampak pada profitabilitas dan periode penangguhan utang yang optimal.

Siklus konversi kas sendiri dapat di breakdown menjadi tiga komponen, yaitu periode konversi persediaan, periode pengumpulan piutang, dan periode penangguhan utang. Perusahaan dapat memperpendek siklus konversi kas dengan cara mempercepat periode pengumpulan piutang dan periode konversi persediaan, dengan secara bersamaan memperlambat periode penangguhan utang (Aditya : 2013)

Evaluasi kinerja perusahaan juga dapat dilakukan menggunakan analisis laporan kevangan. Dimana analisis laporan kevangan dapat dilakukan melalui rasio keuangan.Rasio-rasio yang digunakan untuk menilai kinerja keuangan seperti rasio likuiditas, rasio leverage, rasio aktivitas dan rasio profitabilitas. Analisis rasio memungkinkan manajer keuangan dan pihak yang berkepentingan untuk mengetahui sehat atau tidaknya perusahaan. (Meilinda, 2011:19)

Tabel 1.1

Rata-Rata Return on Asset, Periode Konversi Persediaan, Periode Pengumpulan Piutang, Periode 
Qomaruddin, et al/ Jurnal Ekonomi Syariah Teori dan Terapan Vol. 5 No. 6 Juni 2018: 448-466;

ANALISIS FAKTOR-FAKTOR YANG BERPENGARUH TERHADAP PROFITABILITAS PERUSAHAAN MANUFAKTUR YANG TERDAFTAR PADA ISSI TAHUN 2011-2015

Penangguhan Utang, Current Ratio,

Leverage, dan Debt to Equity Ratio

\begin{tabular}{|l|c|c|c|c|c|}
\hline \multirow{2}{*}{ Variabel } & \multicolumn{5}{|c|}{ Tahun } \\
\cline { 2 - 6 } & 2011 & 2012 & 2013 & 2014 & 2015 \\
\hline ROA (\%) & 12,4 & 11,4 & 9,8 & 9,3 & 8,5 \\
\hline PKP (hari) & 51 & 67 & 63 & 63 & 64 \\
\hline PPP (hari) & 60 & 56 & 56 & 55 & 55 \\
\hline PPU (hari) & 43 & 50 & 55 & 50 & 54 \\
\hline CR (\%) & 249 & 232 & 230 & 243 & 267 \\
\hline Leverage & 0,39 & 0,42 & 0,44 & 0,40 & 0,37 \\
\hline DER & 0,84 & 0,85 & 1,67 & 2,05 & 1,63 \\
\hline
\end{tabular}

Sumber: Website Bursa Efek Indonesia

(www.idx.co.id), Februari 2017

Dalam penelitian sebelumnya

terdapat hasil penelitian yang beragam.

Saghir (2011)menyatakan bahwa

terdapat hubungan negatif antara konversi persediaan dengan profitabilitas.

Lamanya konversi persediaan akan mengurangi profitabilitas karena banyaknya biaya yang harus ditanggung dengan adanya biaya yang terkait dengan persediaan, diantaranya biaya pemeliharaan, sehingga kesempatan untuk produksi berkurang, dan banyaknya persediaan yang menganggur sehingga profitabilitas menurun. Sedangkan Ambrose (2013) menyatakan terdapat hubungan positif antara periode konversi persediaan terhadap profitabilitas.

Tanjung (2013) dan Saghir (2011) mendapatkan hasil yang sama terkait hubungan antara periode pengumpulan piutang dengan profitabilitas, yaitu berpengaruh negatif signifikan karena semakin lama waktu yang dibutuhkan untuk mengumpulkan piutang, akan mengurangi kesempatan perusahaan untuk menginvestasikan dana hasil penarikan piutang tersebut untuk melakuikan kegiatan produksi lebih lanjut. Sedangkan Aini (2012) menyatakan terdapat hubungan positif antara periode pengumpulan piutang dengan profitabilitas.

Terkait dengan pengaruh periode penangguhan utang terhadap profitabilitas, Aini (2012) dan Saghir (2011) memperoleh hasil penelitian bahwa periode penangguhan utang berpengaruh poositif terhadap profitabilitas.

Barus (2013) menyatakan bahwa terdapat hubungan positif antara Current Ratio terhadap profitabilitas sedangkan Hastuti (2010) menyatakan terdapat hyubungan negatif antara Current Ratio terhadap profitabilitas.

Priharyanto (2009) menyatakan bahwa Debt to Equity Ratio berpengaruh negatif terhadap profitabilitas. Semakin banyak modal perusahaan yang dibiayai dari utang akan memperbesar beban perusahaan terkait dengan pembayaran utang tersebut sehingga mengurangi profitabilitas. Sedangkan Barus (2013) menyatakan terdapat hubungan positidf antara Debt to Equity Ratio dan profitabilitas.

Hastuti (2010) menyatakan bahwa terdapat hubungan negatif antara leveragedengan profitabilitas karena banyaknya biaya yang harus ditanggung untuk membayar utang sehingga 
Qomaruddin, et al/ Jurnal Ekonomi Syariah Teori dan Terapan Vol. 5 No. 6 Juni 2018: 448-466;

ANALISIS FAKTOR-FAKTOR YANG BERPENGARUH TERHADAP PROFITABILITAS PERUSAHAAN MANUFAKTUR YANG TERDAFTAR PADA ISSI TAHUN 2011-2015

mengurangi kesempatan untuk

berproduksi. Sesuai dengan Barus (2013)

yang menyatakan bahwa terdapat

hubungan negatif antara leverage

dengan profitabilitas.

Periode Konversi Kas dan Periode

Pengumpulan Piutang berpengaruh negative terhadap profitabilitas, karena kedua variabel tersebut berpotensi mengurangi dana yang sedianya dapat digunakan oleh perusahaan sebagai modal tambahan dalam melakukan kegiatan produksi. Sedangkan Periode penangguhan utang berpengaruh positif terhadap profitabilitas, karena vang yang asalnya akan digunakan untuk membayar utang dapat dipakai dulu untuk tambahan modal proses produksi. Variabel Leverage, Current Ratio dan Debt to Equity Ratio berpengaruh negatif terhadap profit karena semakin besar komposisi utang dalam permodalan, akan berbanding lurus dengan biaya bunga utang yang harus dibayar oleh manajemen perusahaan

\section{TINJAUAN PUSTAKA}

\section{Industri Manufaktur}

Karakteristik utama kegiatan industri manufaktur adalah mengolah sumberdaya menjadi barang jadi melalui suatu proses pabrikasi. Oleh karena itu aktivitas yang tergolong dalam kelompok industri manufaktur sekurang-kurangnya memiliki tiga kegiatan usaha, yaitu:

1. Kegiatan untuk memperoleh atau menyimpan bahan baku.

2. Kegiatan pengolahan/pabrikasi/perakitan atas bahan baku menjadi barang jadi.

3. Menyimpan dan mendistribusikan barang jadi.

[kemenperin.go.id]

\section{Indeks Saham Syariah Indonesia}

Indeks Saham Syariah Indonesia merupakan indeks saham yang mencerminkan keseluruhan saham syariah yang tercatat di BEl dan terdaftar dalam Daftar Efek Syariah (DES). Konstituen ISSI direview setiap enam bulan sekali (Mei dan November) dan dipublikasikan pada awal bulan berikutnya. Konstituen ISSI juga dilakukan penyesuaian jika ada saham syariah yang baru tercatat atau dihapuskan dari DES. Indeks ISSI diluncurkan pada tanggal 12 Mei 2011 (idx.co.id).

\section{Profitabilitas}

Rasio profitabilitas merupakan rasio untuk menilai kemampuan perusahaan dalam mencari keuntungan. Rasio ini juga mengukur tingkat efektivitas manajemen perusahaan. Hal ini ditunjukkan oleh laba yang dihasilkan dari penjualan dan pendapatan investasi (Kasmir, 2013 : 196) .

Brigham dan Houston (2001:89) menyatakan profitabilitas adalah laba bersih dari serangkaian kebijakan dan keputusan. Meski tidak secara terang menyatakan profitabilitas sebagai sebuah laba, namun hal inilah yang akan menentukan untung tidaknya sebuah kegiatan operasional perusahaan.

Brigham dan Houston (2001:90) menyatakan bahwa rasio pengembalian atas total aktiva (ROA) merupakan perbandingan atas laba bersih terhadap 
Qomaruddin, et al/ Jurnal Ekonomi Syariah Teori dan Terapan Vol. 5 No. 6 Juni 2018: 448-466;

ANALISIS FAKTOR-FAKTOR YANG BERPENGARUH TERHADAP PROFITABILITAS PERUSAHAAN MANUFAKTUR YANG TERDAFTAR PADA ISSI TAHUN 2011-2015

total aktiva, akan dapat mengukur pengembalian atas total aktiva setelah bunga dan pajak. Pengembalian perusahaan yang semakin menurun dapat disebabkan oleh rendahnya basic earning power perusahaan dan tingginya biaya bunga karena penggunaan kewajiban diatas rata-rata sehingga menyebabkan laba bersih yang relatif rendah. Rumus ROA adalah sebagai berikut:

$$
\begin{aligned}
& \text { ROA = Laba Bersih } \\
& \text { Total Aktiva }
\end{aligned}
$$

\section{Konsep Modal Kerja}

Suatu analisa terhadap sumber dan penggunaan modal kerja sangat penting bagi penganalisa intern maupun ekstern, disamping karena masalah modal kerja ini erat hubungannya dengan operasi perusahaan sehari-hari juga menunjukkan tingkat keamanan para kreditur, terutama kreditur jangka pendek.

Modal kerja diartikan sebagai investasi yang ditanamkan dalam aktiva lancar seperti: kas, piutang, surat berharga dan persediaan(Sudana, 2011:189)]. Manajemen modal kerja melibatkan penentuan tingkat kas, efek yang diperjual-belikan, piutang usaha, serta persediaan yang optimal dan mendanai aset-aset tersebut semurah mungkin (Brigham, 2006:257)

\section{Periode Konversi Persediaan}

Persediaaan memungkinkan pihak manajemen perusahaan untuk mengatur kegiatan pengadaan profitabilitas dan penjualan agar lebih fleksibel, memperkecil kemungkinan perusahaan gagal memenuhi permintaan pelanggan, atau terhentinya proses profitabilitas dikarenakan tidak adanya persediaan bahan baku. Dengan mengadakan persediaan perusahaan dapat memanfaatkan kesempatan memperoleh potongan harga dari pemasok. Pengadaan persediaan juga dimaksudkan untuk menghindari fluktuasi harga yang meningkat, serta sebagai persediaan pengaman untuk menghadapi kondisi yang tidak pasti. Berdasar uraian ini, maka manajemen harus mampu menentukan tingkat persediaan yang optimal dan periode konversi persediaan tersebut (Sudana, 2011: 225).

Ayat Al-Qur'an yang memberikan gambaran tentang sistem persediaan terdapat dalam Surah Yusuf ayat 43,47 dan ayat 48 .

Makna yang dapat diambil dari ayat tersebut adalah sistem persediaan sudah dikenal pada masa Nabi Yusuf yakni mempersiapkan barang jadi untuk dipersiapkan di kemudian hari menggantikan barang yang telah terjual. Hal ini merupakan sebuah rutinitas yang harus dilakukan oleh perusahaan yang bergerak dibidang manufaktur agar barang yang terjual tergantikan dengan persediaan barang baru dan meningkatkan perputaran persediaan tersebut, sehingga dengan perputaran yang lebih cepat dapat menaikkan profit perusahaan karena terjadi peningkatan penjualan. ( Herdayanti, 2015) 
Qomaruddin, et al/ Jurnal Ekonomi Syariah Teori dan Terapan Vol. 5 No. 6 Juni 2018: 448-466;

ANALISIS FAKTOR-FAKTOR YANG BERPENGARUH TERHADAP PROFITABILITAS PERUSAHAAN MANUFAKTUR YANG TERDAFTAR PADA ISSI TAHUN 2011-2015

Periode konversi Persediaan (inventory conversion periods) adalah rata-rata waktu yang dibutuhkan untuk mengonversi bahan baku menjadi barang jadi dan kemudian menjual barang tersebut. Periode konversi persediaan dihitung dengan membagi persediaan oleh jumlah penjualan perhari (Brigham, 2006: 133) dan dapat dihitung dengan:

Periode konversi persediaan= 365/perputaran persediaan

Perputaran persediaan $=$ Penjualan $/$ Rata rata persediaan

Periode Pengumpulan Piutang

Mamduh (2008:554) berpendapat bahwa Piutang dagang merupakan komponen aktiva lancar yang cukup penting. Secara umum perusahaan akan menjual secara tunai, karena akan menerima kas dan memperpendek siklus kas. Piutang dagang muncul ketika penjualan terjadi, tapi perusahaan belum menerima kas. Dengan demikian penggunaan piutang diharapkan dapat meningkatkan penjualan dan keuntungan, tapi dilain pihak piutang juga menyebabkan peningkatan biaya yang terkait dengan piutang. Biaya tersebut antara lain biaya kesempatan karena dana tertanam pada investasi piutang dan piutang yang tidak terbayar.

Mamduh (2008:554) berpendapat bahwa semakin tinggi piutang dagang maka semakin tinggi biaya yang berkaitan dengan piutang tersebut, tetapi semakin tinggi piutang dagang, semakin tinggi tingkat penjualan yang diharapkan.Periode pengumpulan piutang (receivables conversion periods) adalah rata-rata waktu yang dibutuhkan untuk mengonversi piutang perusahaan menjadi kas yaitu, untuk menerima kas setelah terjadi penjualan. Periode pengumpulan piutang disebut juga jumlah hari penjualan belum tertagih (day sales outstanding) dan dihitung dengan membagi piutang oleh rata-rata penjualan kredit perhari (Brigham, 2006: 134). Semakin lama periode pengumpulan piutang berarti pendapatan yang akan diterima perusahaan tertunda, dampaknya akan menghambat perusahaan memperoleh laba dengan cepat sehingga laba tahun tersebut menjadi mengalami penurunan.

Dengan demikian Islam telah mengenal sistem akuntansi. Ayat diatas menjelaskan tentang sistem pencatatan jika terjadi hutang piutang. Catatan tersebut digunakan sebagai bukti bahwa telah terjadi transaksi sebesar nominal tertentu dan belum ada pembayaran sehingga perusahaan harus ditulis atau dicatat dalam suatu laporan keuangan agar jelas bagi pihak-pihak yang terlibat

\section{Periode Penangguhan Utang}

Utang dagang dapat menghasilkan tambahan permodalan. Apabila pembayaran utang dagang diperlama, maka tambahan modal yang dimiliki dapat digunakan untuk melakukan investasi. Dengan adanya investasi maka perusahaan dapat melakukan kegiatan profitabilitas dengan lebih efektif. Islam juga telah mengatur bagaimana sebaiknya dalam bermuamalah utang 
Qomaruddin, et al/ Jurnal Ekonomi Syariah Teori dan Terapan Vol. 5 No. 6 Juni 2018: 448-466; ANALISIS FAKTOR-FAKTOR YANG BERPENGARUH TERHADAP PROFITABILITAS PERUSAHAAN MANUFAKTUR YANG TERDAFTAR PADA ISSI TAHUN 2011-2015

yaitu terdapat dalam Al Baqoroh ayat 280:

Periode penangguhan utang (Payable defferal periods) adalah rata-rata waktu yang dibutuhkan untuk membeli bahan baku dan tenaga kerja dan pembayarannya (Brigham, 2006:134), dengan asumsi semua pembelian bahan baku dan tenaga kerja secara utang atau dibiayai dengan utang dagang, perhitungan periode penangguhan utang diproyeksikan sebagai berikut :

Periode Penangguhan Utang= 365/Perputaran Utang

Perputaran Utang $=$ Harga Pokok Penjualan/Rata-rata Utang Dagang

\section{Rasio Leverage}

Rasio ini merupakan rasio antara total utang (total debts) baik utang jangka pendek maupun utang jangka panjang terhadap total aktiva (total assets) baik asset lancar maupun aktiva tetap dan aktiva lainnya (Mamduh, 2008:40) dan dapat dihitung dengan : Total Debt to Total Assets Ratio =Total Utang $/$ Total Aktiva.

Rasio ini menunjukkan besarnya utang yang digunakan oleh perusahaan dalam rangka menjalankan aktivitas operasionalnya. Semakin besar rasio Debt to Total Assets menunjukkan semakin besar tingkat ketergantungan perusahaan terhadap pihak eksternal (kreditur) dan semakin besar pula beban biaya bunga yang harus dibayar oleh perusahaan. Dengan semakin meningkatnya rasio Debt to Total Assets (dimana beban utang juga semakin besar) maka hal tersebut berdampak terhadap profitabilitas yang diperoleh perusahaan karena sebagian digunakan untuk membayar bunga pinjaman.

Dalam islam, hukum mengelola perusahaan dengan dana pinjaman adalah boleh, namun harus diingat bahwa penggunaan dana pinjaman ini harus proporsional dan tidak berlebihan sehingga tidak memberatkan dikemudian hari. Rasulullah SAW sangat hati-hati dalam berhutang, dan diriwayatkan dari Aisyah R.A, beliau seringkali berdoa agar terhindar dari hutang

\section{Current Ratio}

Current Ratio adalah rasio yang digunakan untuk mengukur kemampuan perusahaan dalam memenuhi kewajibannya. Semakin rendahnya nilai CR mengindikasikan ketidakmampuan perusahaan dalam memenuhi kewajiban jangka pendeknya, sehingga hal ini dapat mempengaruhi tingkat profitabilitas perusahaan, dimana perusahaan yang tidak mampu memenuhi kewajibannya akandikenai beban tambahan (Andreani, 2013: 112)

Current Ratio =Aktiva Lancar/Kewajiban Jangka Pendek

Bahaya bagi seorang pengusaha muslim jika tidak mampu melunasi hutangnya dijelaskan pada hadits berikut:

\section{Debt to Equity Ratio}

Debt to Equity Ratio merupakan perbandingan antara jumlah utang perusahaan terhadap total ekuitas atau dengan katalain menunjukkan kemampuan perusahaan 
Qomaruddin, et al/ Jurnal Ekonomi Syariah Teori dan Terapan Vol. 5 No. 6 Juni 2018: 448-466; ANALISIS FAKTOR-FAKTOR YANG BERPENGARUH TERHADAP PROFITABILITAS PERUSAHAAN MANUFAKTUR YANG TERDAFTAR PADA ISSI TAHUN 2011-2015

memenuhikebutuhan operasionalnya dengan modal sendiri. Artinya, semakin banyak modal sendiri yang digunakan untuk menjalankan kegiatan operasional, semakin kecil pula pinjaman dilakukan sehingga meminimalkan kewajiban dalam pembayaran bunga bagi perusahaan.

Debt to Equity Ratio =Total Debt to Total Equity

Rasulullah mengajarkan, apabila memang kita berniat untuk berhutang, maka kita harus berkomitmen untuk benar-benar melunasi hutang tersebut ketika telah jatuh tempo

Barangsiapa yang meminjam harta manusia dan ia berniat melunasinya, maka Allah akan membantu pelunasannya, namun bila ia tidak berniat melunasinya, maka Allah akan menghilangkan harta tersebut darinya ."(H.R Al Bukhari no.2387) (Muslim.or.id, Edisi !8 April 2013)

\section{Hipotesis}

Berdasarkan Penjabaran yang telah dipaparkan sebelumnya, maka dapat diambil hipotesis sebagai berikut.

a. Terdapat pengaruh periode konversi persediaan, periode pengumpulan piutang, periode penangguhan utang, Current Ratio, Leverage, Debt To Equity Ratio terhadap profitabilitas pada Perusahaan Manufaktur secara simultan.

b. Terdapat pengaruh periode konversi persediaan, periode pengumpulan piutang, periode penangguhan utang, Current Ratio, Leverage, Debt To Equity Ratio dan ukuran perusahaan terhadap profitabilitas pada Perusahaan Manufaktur secara parsial.

\section{METODE PENELITIAN}

\section{Pendekatan Penelitian}

Penelitian ini menggunakan pendekatan kuantitatif untuk menjawab rumusan masalah. Pendekatan kuantitatif ini menitikberatkan pada pengujian hipotesis, menggunakan data-data yang terukur dan alat analisis statistik inferensial parametric.

\section{Identifikasi Variabel}

Berdasarkan model analisis dan hipotesis penelitian maka variabel-variabel yang akan digunakan dalam penelitian ini dapat diklasifikasikan sebagai berikut :

a. Variabel dependen dari penelitian ini adalah Profitabilitas / ROA (Y).

b. Variabel Independen adalah variabel bebas yang mempengaruhi atau menjadi penyebab berubahnya variabel dependen. Variabel Independen pada penelitian ini terdiri dari.

a) Periode Konversi Persediaan $\left(X_{1}\right)$

b) Periode Pengumpulan Piutang $\left(\mathrm{X}_{2}\right)$

c) Periode Penangguhan Utang $\left(X_{3}\right)$
d) Leverage $\left(X_{4}\right)$
e) Debt to Equity Ratio $\left(X_{5}\right)$
f) Current Ratio $\left(X_{6}\right)$

\section{Definisi Operasional Variabel}

Pada penelitian ini, definisi operasional diperlukan pada variabel manifest yang dapat diobservasi secara langsung. 
Qomaruddin, et al/ Jurnal Ekonomi Syariah Teori dan Terapan Vol. 5 No. 6 Juni 2018: 448-466;

ANALISIS FAKTOR-FAKTOR YANG BERPENGARUH TERHADAP PROFITABILITAS PERUSAHAAN MANUFAKTUR YANG TERDAFTAR PADA ISSI TAHUN 2011-2015

Profitabilitas

Variabel ROA merupakan variabel dependen dalam penelitian ini. Data ROA bersumber dari Laporan KeuanganPerusahaan Manufaktur periode Januari 2011- Desember 2015 yang berjumlah 30 data. Return On Assets (ROA) diperoleh dari perhitungan laba sebelum pajak (return) dibagi total aktiva.

\section{Periode Konversi Persediaan}

Periode konversi Persediaan (inventory conversion periods) adalah rata-rata waktu yang dibutuhkan untuk mengonversi bahan baku menjadi barang jadi dan kemudian menjual barang tersebut (Brigham \& Houston, 2006: 133) dan dapat dihitung dengan:

Periode Konversi Persediaan= 365/Perputaran persediaan

Perputaran persediaan $=$ Penjualan $/$ Ratarata persediaan

\section{Periode Pengumpulan Piutang}

Periode pengumpulan piutang (receivables conversion periods) adalah rata-rata waktu yang dibutuhkan untuk mengonversi piutang perusahaan menjadi kas yaitu, untuk menerima kas setelah terjadi penjualan. Periode pengumpulan piutang disebut juga jumlah hari penjualan belum tertagih (day sales outstanding) dan dihitung dengan membagi piutang oleh rata-rata penjualan kredit perhari (Brigham \& Houston, 2006: 134). Dengan asumsi semua penjualan adalah kredit, perhitungan periode pengumpulan piutang diproyeksikan dengan:
Periode Pengumpulan Piutang= 365/Perputaran Piutang

Perputaran Piutang $=$ Penjualan/Rata-rata piutang

\section{Periode Penangguhan Utang}

Utang dagang dapat menghasilkan tambahan permodalan. Apabila pembayaran utang dagang diperlama, maka tambahan modal yang dimiliki dapat digunakan untuk melakukan investasi. Dengan adanya investasi maka perusahaan dapat melakukan kegiatan profitabilitas dengan lebih efektif.

Periode penangguhan utang (Payable defferal periods) adalah rata-rata waktu yang dibutuhkan untuk membeli bahan baku dan tenaga kerja dan pembayarannya (Brigham \& Houston, 2006:134), dengan asumsi semua pembelian bahan baku dan tenaga kerja secara utang atau dibiayai dengan utang dagang, perhitungan periode penangguhan utang diproyeksikan sebagai berikut:

Periode Penangguhan Utang= 365/Perputaran Utang

Perputaran Utang $=$ Harga Pokok Penjualan/Rata-rata Utang Dagang

\section{Leverage}

Leverage merupakan rasio yang digunakan untuk mengukur tingkat penggunaan hutang terhadap total asset yang dimiliki. Semakin tinggi jumlah utang yang digunakan untuk membeli asset akan menyebabkan semakin tingginya bunga pinjaman yang ditanggung oleh perusahaan, sehingga jumlah laba yang mampu diperoleh semakin rendah 
Qomaruddin, et al/ Jurnal Ekonomi Syariah Teori dan Terapan Vol. 5 No. 6 Juni 2018: 448-466; ANALISIS FAKTOR-FAKTOR YANG BERPENGARUH TERHADAP PROFITABILITAS PERUSAHAAN MANUFAKTUR YANG TERDAFTAR PADA ISSI TAHUN 2011-2015

Total Debt to Total Assets Ratio =Total Utang/ Total Aktiva

\section{Current Ratio}

Current Ratio adalah rasio yang digunakan untuk mengukur kemampuan perusahaan dalam memenuhi kewajibannya. Semakin rendahnya nilai CR mengindikasikan ketidakmampuan perusahaan dalam memenuhi kewajiban jangka pendeknya, sehingga hal ini dapat mempengaruhi tingkat profitabilitas perusahaan, dimana perusahaan yang tidak mampu memenuhi kewajibannya akan dikenai beban tambahan (Andreani, 2013: 112)

Current Ratio =Aktiva Lancar/Kewajiban Jangka Pendek

\section{Debt to Equity Ratio}

Debt to Equity Ratio merupakan perbandingan antara jumlah utang perusahaan terhadap total ekuitas atau dengan katalain menunjukkan kemampuan perusahaan memenuhikebutuhan operasionalnya dengan modal sendiri. Artinya, semakin banyak modal sendiri yang digunakan untuk menjalankan kegiatan operasional, semakin kecil pula pinjaman dilakukan sehingga meminimalkan kewajiban dalam pembayaran bunga bagi perusahaan.

Debt to Equity Ratio =Total Debt to Total Equity

\section{Jenis dan Sumber Data}

Jenis data yang digunakan dalam penelitian ini adalah data sekunder berupa laporan keuangan perusahaan yang diperoleh dari laporan tahunan perusahaan sektor manufaktur yang go public di ISSI periode 2011-2015. Karena penelitian ini menyangkut perusahaan publik, maka data yang digunakan adalah laporan keuangan yang dipublikasikan. Data tersebut diperoleh dari website resmi BEl (idx/internet data exchange).

\section{Populasi}

Populasi dalam penelitian ini adalah seluruh perusahaan manufaktur yang tercatat di Indeks Saham Syariah Indonesia dari periode Januari 2011Desember 2015.

\section{Sampel}

Sampel dalam penelitian diambil secara sengaja (Purposive Sampling), maksudnya menentukan sendiri sampel yang diambil karena pertimbangan tertentu. Jadi, sampel diambil tidak secara acak tetapi ditentukan sendiri oleh peneliti. Kriteria pengambilan sampel dalam penelitian ini adalah sebagai berikut:

1. Perusahaan manufaktur yang terdaftar di ISSI yang menerbitkan dan mempublikasikan laporan keuangan tahunan secara lengkap dari tahun 2011 hingga tahun 2015.

2. Perusahaan yang selalu menyediakan data lengkap mengenai rasio keuangan selama periode pengamatan.

3. Perusahaan yang memiliki ROA positif, agar rata-rata ROA tidak bernilai nol.

4. Perusahaan manufaktur yang selalu terdaftar di ISSI selama periode penelitian, yaitu tahun 2011 hingga 2015.

\section{Prosedur Pengumpulan Data}


Qomaruddin, et al/ Jurnal Ekonomi Syariah Teori dan Terapan Vol. 5 No. 6 Juni 2018: 448-466; ANALISIS FAKTOR-FAKTOR YANG BERPENGARUH TERHADAP PROFITABILITAS PERUSAHAAN MANUFAKTUR YANG TERDAFTAR PADA ISSI TAHUN 2011-2015

Data yang digunakan dalam penelitian ini adalah data sekunder bersifat kuantitatif, berupa rasio-rasio keuangan yang terbit setiap akhir periode yang diterbitkan melalui website resmi BEI (idx/internet data exchange) dengan metode Dokumentasi. Prosedur pengumpulan data juga melalui studi pustaka yaitu mengkaji buku-buku, jurnal, skripsi dan lain-lain yang berkaitan dengan penelitian. Hal tersebut dilakukan untuk memperoleh landasan teori yang komprehensif (mudah dipahami).

\section{Teknik Analisis}

\section{Metode Regresi Data Panel}

Penelitian ini menggunakan teknik analisis regresi berganda data panel. Menurut Gujarati (2003), ada tiga metode yang dapat digunakan untuk mengestimasi teknik analisis regresi data panel:

\section{Metode Pooled Least Square (PLS)}

Metode PLS merupakan salah satu metode yang digunakan dalam data panel dengan cara mengestimasi data panel dengan metode Ordinary Least Square (OLS). Metode ini secara sederhana menggabungkan seluruh data time series dan cross section.. Metode ini memperhitungkan kemungkinan bahwa peneliti akan menghadapi masalah ommited variablesyang memungkinkan membawa perubahan pada intercept time series atau cross section.

\section{Metode Fixed Effect Model (FEM)}

Metode FEM merupakan metode yang digunakan dalam data panel dengan cara menambahkan dummy pada variabel yang membutuhkan variabel dummy pada data panel, penambahan dummy mengizinkan adanya sebuah perubahan dalam intercept.

\section{Metode Random Effect Model (REM)}

Metode REM ini merupakan metode yang digunakan dalam data panel dengan cara memperhitungkan error dari data dengan metode least square. Metode ini merupakan perbaikan dari metode least square dengan memperhitungkan error dari data time series dan cross section.

\section{Estimasi Metode Regresi Panel}

Estimasi model regresi data panel terdapat uji Redundant dan uji Haussman. Uji Redundant dapat digunakan untuk memilih teknik dengan model pendekatan PLS atau FEM, dengan rumus sebagai berikut:

$\mathrm{F} \quad\left(\begin{array}{lllll}\mathrm{R}^{2} \mathrm{ur} & - & \mathrm{R}^{2} \mathrm{r}\end{array}\right) \quad / \quad \mathrm{m}$

$\left(1-R^{2} r\right) /(n-k)$

Dimana:

$$
\begin{array}{ll}
\mathrm{R}^{2} \mathrm{r} & =\mathrm{R}^{2} \text { model PLS } \\
\mathrm{R}^{2} \mathrm{Ur} & =\mathrm{R}^{2} \text { model FEM } \\
\mathrm{m} & =\text { Jumlah restricted variable } \\
\mathrm{n} & =\text { Jumlah sampel } \\
\mathrm{k} & =\text { Jumlah variabel penjelas }
\end{array}
$$

Hipotesis nol dari restrictedRedundant test adalah sebagai berikut:

$\mathrm{H}_{0}=$ model pooled least square(restricted)

$\mathrm{H}_{1} \quad=$ model fixed effect (unristricted) Berdasarkan persamaan diatas apabila memperoleh hasil $F$ hitung $>F$ Tabel pada tingkat keyakinan tertentu, maka artinya menolak hipotesis $\mathrm{H}_{0}$ yang menyatakan harus memilih teknik PLS atau menerima 
Qomaruddin, et al/ Jurnal Ekonomi Syariah Teori dan Terapan Vol. 5 No. 6 Juni 2018: 448-466; ANALISIS FAKTOR-FAKTOR YANG BERPENGARUH TERHADAP PROFITABILITAS PERUSAHAAN MANUFAKTUR YANG TERDAFTAR PADA ISSI TAHUN 2011-2015

hipotesis $H_{1}$ yang menyatakan harus menggunakan metode fixed effect model untuk teknik analisis dalam penelitian.

Selain itu, uji Haussman digunakan untuk memilih antara metode pendekatan FEM atau REM. Hipotesis nol dari uji Haussman adalah sebagai berikut: $\mathrm{H}_{0}=$ menggunakan metode Random Effect Model.

$\mathrm{H}_{1}=$ menggunakan metode Fixed Effect Model

Apabila chi-square hitung > chi-square Tabel, dan p-value signifikan, maka $\mathrm{H}_{0}$ ditolak dan model FEM lebih tepat digunakan. Dengan kata lain menolak $\mathrm{H}_{0}$ dan menerima $\mathrm{H}_{1}$.

\section{Uji Statistik}

Uji t-statistik

Uji $†$ merupakan pengujian yang dilakukan terhadap koefisien variabel independen atau variabel bebas. Uji $†$ dilakukan dengan cara membandingkan nilai hasil uji † statistik dengan nilai dari $\dagger$ Tabel. Jika nilai dari $\dagger$ stat $>$ † Tabel, maka $\mathrm{H}_{0}$ ditolak dan $\mathrm{H}_{1}$ diterima, atau dengan kata lain terdapat hubungan antara variabel dependen dan variabel independen. Sebaliknya, jika + stat < † Tabel maka $H_{0}$ diterima dan $H_{1}$ ditolak yang dapat diartikan bahwa tidak ada hubungan antara variabel dependen dan variabel independen.

\section{Uji F-statistik}

Uji $F$ dapat dilakukan dengan cara membandingkan nilai hasil uji F-statistik pada hasil regresi dengan $F$ Tabel. Jika $F$ stat > F Tabel, maka $\mathrm{H}_{0}$ ditolak dan $\mathrm{H}_{1}$ diterima, atau dengan kata lain terdapat hubungan antara variabel dependen dengan variabel independen. Sebaliknya, jika F stat < F Tabel maka $\mathrm{H}_{0}$ diterima dan $\mathrm{H}_{1}$ ditolak atau dengan kata lain tidak terdapat hubungan antara variabel dependen dan variabel independen.

\section{Koefisien Determinasi}

$R^{2}$ sering juga disebut $R^{2}$ adjusted. $R^{2}$ adjusted ini menunjukkan kemampuan garis regresi dalam menerangkan seberapa besar variabel independen dapat menerangkan dan mejelaskan variabel dependen. Nilai dari $R^{2}$ adjusted berkisar antara 0 sampai dengan 1 . Semakin mendekati 1, maka akan semakin baik karena semakin dapat menjelaskan variasi variabel dependen.

\section{HASIL DAN PEMBAHASAN}

\section{Analisis Hasil Penelitian}

\section{Pemodelan Profitabilitas Perusahaan Manufaktur}

Pemilihan model estimasi dengan menggunakan data panel terdiri dari dua tahap pengujian, yaitu F-statistik dan Uji Haussman. Uji F-statistik digunakan untuk memilih metode terbaik dari Pooled Least Square (PLS) dan Fixed Effect Model (FEM). Sedangkan uji Haussman digunakan untuk memilih metode terbaik antara Fixed Effect Model dan Random Effect Model

Berdasarkan hasil uji F-statistikdiperoleh kesimpulan bahwa menerima $H_{1}$ yang berarti lebih baik menggunakan metode Fixed Effect Model. Oleh karena itu selanjutnya diperlukan Uji Haussman untuk mengetahui metode yang digunakan 
Qomaruddin, et al/ Jurnal Ekonomi Syariah Teori dan Terapan Vol. 5 No. 6 Juni 2018: 448-466;

ANALISIS FAKTOR-FAKTOR YANG BERPENGARUH TERHADAP PROFITABILITAS PERUSAHAAN MANUFAKTUR YANG TERDAFTAR PADA ISSI TAHUN 2011-2015

antara Fixed Effect Model dan Random Log

Effect Model.

Berdasarkan hasil uji Haussman diperoleh kesimpulan dari uji Haussman diatas likelihoo

d $\quad-410.9087$ Hannan-Quinn criter.

F-

statistic $\quad 5.166446$ Durbin-Watson stat

adalah menerima $\mathrm{H}_{1}$, sehingga penelitian

ini tetap lebih baik menggunakan metode

Fixed Effect Model. Berikut ini adalah hasil

estimasi fixed effect modelperusahaan

manufaktur pada Tabel 4.11 dibawah ini.

Tabel 4.11

Hasil Estimasi dengan Fixed Effect Model EViews 6

\section{UjiStatistik}

\section{Uji t-statistik}

Nilai t-hitung masing-masing variabel bebas perusahaan manufaktur dihasilkan dari estimasi regresi data panel yang ditampilkan pada Tabel 4.11. Identifikasi

Dependent Variable: $Y$

Method: Panel Least Squares nilai t-hitung untuk tiap variabel bebas adalah sebagai berikut:

Date: 02/17/17 Time: 02:41

Variabel periode konversi persediaan (X1)

Sample: 20112015

memiliki probabilitas t-hitung sebesar

Periods included: 5

0.1223 dengan nilai koefisien -0.030147 .

Cross-sections included: 30

Total panel (unbalanced) observations: 147

Nilai probabilitas tersebut tidak signifikan pada tingkat keyakinan a sebesar 5\%

\begin{tabular}{|c|c|c|c|c|}
\hline Variable & Coefficient & Std. Error & t-Statistic & 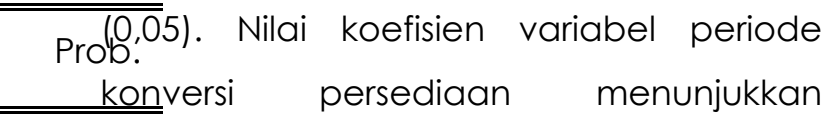 \\
\hline C & 2744 & & $z$ & 0.0B0bungan \\
\hline $\mathrm{X} 1$ & -0.030147 & 0.019362 & -1.557023 & 0.1 Rzafitabilitas, yaitu setiap keno \\
\hline $\mathrm{X} 2$ & 0.028886 & 0.029415 & 0.982010 & 0.3zвeziode konversi persediaan 1 sa \\
\hline$x 3$ & -0.078664 & 0.022642 & -3.474285 & akan turun \\
\hline $\mathrm{X} 4$ & -0.954778 & 4.888915 & -0.195295 & dengan asumsi var \\
\hline X5 & -0.211841 & 0.240451 & -0.881016 & 0.318 \\
\hline X6 & 05080 & 0.006029 & 0.842593 & pulan \\
\hline & Effects S & ation & & $\begin{array}{l}\text { memiliki probabilitas t-hitung seb } \\
0,3282 \text { dengan nilai koefisien seb }\end{array}$ \\
\hline oss-s & $\mathrm{nr}$ & ariables) & & $\begin{array}{l}\text { 0.028886. Nilai probabilitas tersebut tid } \\
\text { sifikan pada tingkat keyakinan }\end{array}$ \\
\hline $\begin{array}{l}\text { R- } \\
\text { squared } \\
\text { Adjuste } \\
\text { d R- } \\
\text { squared } \\
\text { S.E. of }\end{array}$ & 0.619636 & \multicolumn{2}{|l|}{ Mean dependent var } & $\begin{array}{c}10.005 \text { \& Besar } 5 \%(0,05) \text {. Nilai koefisien variabel } \\
\text { periode pengumpulan piutang } \\
6.443584 \text { menunjukkan hubungan positif dengan }\end{array}$ \\
\hline gressio & 4.557663 & Akaike info criterion & & $\begin{array}{l}\text { 6.080BQniabel profitabilitas, yaitu seti } \\
\text { kenaikan periode pengumpulan piutans }\end{array}$ \\
\hline $\begin{array}{l}\text { Jared } \\
\text { id }\end{array}$ & 05.724 & Schwarz Cl & & 6.812741 \\
\hline
\end{tabular}


Qomaruddin, et al/ Jurnal Ekonomi Syariah Teori dan Terapan Vol. 5 No. 6 Juni 2018: 448-466; ANALISIS FAKTOR-FAKTOR YANG BERPENGARUH TERHADAP PROFITABILITAS PERUSAHAAN MANUFAKTUR YANG TERDAFTAR PADA ISSI TAHUN 2011-2015

manufaktur akan naik sebesar 0.028886

persen dengan asumsi variabel lain dianggap tetap.

Variabel periode penangguhan utang (X3) memiliki probabilitas t-hitung sebesar 0,0007 dengan nilai koefisien sebesar 0.078664 .Nilai probabilitas tersebut signifikan pada tingkat keyakinan a sebesar $5 \%(0,05)$. Nilai koefisien variabel periode pengumpulan piutang menunjukkan hubungan negatif dengan variabel profitabilitas, yaitu setiap kenaikan periode penangguhan utang 1 satuan maka profitabilitas perusahaan manufaktur akan turun sebesar 0.078664 persen dengan asumsi variabel lain dianggap tetap.

Variabel Leverage (X4) memiliki probabilitas t-hitung sebesar 0,8455 dengan nilai koefisien sebesar -0.954778 . Nilai probabilitas tersebut tidak signifikan pada tingkat keyakinan a sebesar $5 \%$ $(0,05)$. Nilai koefisien variabel leverage menunjukkan hubungan negatif dengan variabel profitabilitas, yaitu setiap kenaikan leverage 1 satuan maka profitabilitas perusahaan manufaktur akan turun sebesar 0.954778 persen dengan asumsi variabel lain dianggap tetap

Variabel Debt to Equity Ratio (X5) memiliki probabilitas t-hitung sebesar 0,3802 dengan nilai koefisien sebesar -0.211841 Nilai probabilitas tersebut tidak signifikan pada tingkat keyakinan a sebesar 5\% $(0,05)$. Nilai koefisien variabel Debt to Equity Ratio menunjukkan hubungan negatif dengan variabel profitabilitas, yaitu setiap kenaikan Debt to Equity Ratio
1 satuan maka profitabilitas perusahaan manufaktur akan turun sebesar 0.211841 persen dengan asumsi variabel lain dianggap tetap.

Variabel Current Ratio (X6) memiliki probabilitas t-hitung sebesar 0,4013 dengan nilai koefisien sebesar 0.005080 . Nilai probabilitas tersebut tidak signifikan pada tingkat keyakinan a sebesar 5\% $(0,05)$. Nilai koefisien variabel Current Ratio menunjukkan hubungan positif dengan variabel profitabilitas, yaitu setiap kenaikan periode pengumpulan piutang 1 satuan maka profitabilitas perusahaan manufaktur akan naik sebesar 0.005080 persen dengan asumsi variabel lain dianggap tetap

Uji F-statistik

Uji F-statistik digunakan untuk mengetahui pengaruh variabel secara simultan antara variabel bebas dan variabel terikat, pembuktian dari ada atau tidaknya pengaruh ditunjukkan dari nilai probabilitas F-statistik. Hasil perhitungan regresi ditunjukkan dari nilai probabilitas F-statistik. Hasil perhitungan regresi yang ditunjukkan pada Tabel 4.11 menunjukkan nilai probabilitas Fstatistik sebesar 0,0000 . Nilai probabilitas ini signifikan pada tingkat keyakinan $5 \%$ $(0,05)$. Maka dapat ditarik kesimpulan bahwa variabel periode konversi persediaan dan periode pengumpulan piutangsecara simultan atau secara bersama-sama berpengaruh signifikan terhadap variabel profitabilitas perusahaan manufaktur yang terdaftar pada ISSI. 
Qomaruddin, et al/ Jurnal Ekonomi Syariah Teori dan Terapan Vol. 5 No. 6 Juni 2018: 448-466; ANALISIS FAKTOR-FAKTOR YANG BERPENGARUH TERHADAP PROFITABILITAS PERUSAHAAN MANUFAKTUR YANG TERDAFTAR PADA ISSI TAHUN 2011-2015

\section{Koefisien Determinasi $\left(\mathbf{R}^{2}\right)$}

Koefisien determinasi menunjukkan kemampuan variabel bebas dalam menjelaskan variabel dari perubahan variabel terikat secara bersama-sama. Berdasarkan hasil estimasiSedangkan sisamya sebesar $38 \%$ dijelaskan oleh variabel lain diluar model.

\section{Pembuktian Hipotesis}

Sesuai dengan hipotesis yang telah dibuat, terdapat dugaan yaitu hubungan antara variabel independen terhadap profitabilitas perusahaan manufaktur, baik secara parsial maupun juga simultan. Untuk membuktikan dugaan tersebut dapat dilihat dari hasil uji t-statistik dan hasil uji F-statistik. Hasil uji tersebut adalah sebagai berikut:

Tabel 4.12

Uji Hipotesis Profitabilitas Perusahaan manufaktur

\begin{tabular}{|c|c|c|}
\hline Variabel & t-statistik & Probabilitas \\
\hline $\begin{array}{l}\text { Periode konversi } \\
\text { persediaan }\end{array}$ & -1.557023 & 0.1223 \\
\hline $\begin{array}{c}\text { Periode } \\
\text { Pengumpulan } \\
\text { Piutang }\end{array}$ & 0.982010 & 0.3282 \\
\hline $\begin{array}{c}\text { Periode } \\
\text { Penangguhan Utang }\end{array}$ & -3.474285 & 0.0007 \\
\hline Leverage & -0.195295 & 0.8455 \\
\hline Debt To Equity Ratio & -0.881016 & 0.8032 \\
\hline Current Ratio & 0.842593 & 0.4013 \\
\hline \multicolumn{2}{|l|}{ F-Statistik } & 5.166446 \\
\hline \multicolumn{2}{|l|}{ Probabilitas F-Statistik } & 0.000000 \\
\hline
\end{tabular}

Sumber: Hasil Uji E-Views 6

Berdasarkan hasil dari uji t-statistik dan uji F-statistik maka dapat disimpulkan bahwa variabel variabel indepen terbukti berpengaruh secara simultan terhadap variabel profitabilitas perusahaan manufaktur di Indeks Saham Syariah Indonesia tahun 2011-20115. Variabel periode penangguhan utang terbukti berpengaruh signifikan secara parsial terhadap variabel profitabilitas perusahaan manufaktur Indeks Saham Syariah Indonesia tahun 2011-20115.

\section{Pembahasan}

Pengaruh Periode Konversi Persediaan, Periode Pengumpulan Piutang, Periode Penangguhan Utang, Leverage, Debt to Equity Ratio dan Current Ratio Secara Simultan Terhadap Profitabilitas Perusahaan Manufaktur pada Indeks Saham Syariah Indonesia

Hasil penelitian ini menunjukkan bahwa Periode Konversi Persediaan, Periode Pengumpulan Piutang, Periode Penangguhan Utang, Leverage, Debt to Equity Ratio dan Current Ratio secara simultan berpengaruh signifikan terhadap profitabilitas. Hal ini terlihat dari $p$-value uji$F$ lebih kecil dari a $(0,000<0,005)$ sehingga variabel independen secara simultan berpengaruh terhadap profitabilitas. Dapat disimpulkan bahwa pihak manajemen perusahaan harus fokus pada variabel-variabel independen untuk mendapatkan keuntungan optimal.

Pengaruh Periode Konversi Persediaan, Periode Pengumpulan Piutang, Periode Penangguhan Utang, Leverage, Debt to Equity Ratio dan Current Ratio Secara Parsial Terhadap Profitabilitas Perusahaan Manufaktur pada Indeks Saham Syariah Indonesia.

Pengaruh Periode Konversi Persediaan Terhadap Profitabilitas Perusahaan Manufaktur pada Indeks Saham Syariah Indonesia.

Pengaruh Periode Konversi Persediaan terhadap profitabilitas secara parsial dapat dilihat melalui hasil pengujian 
Qomaruddin, et al/ Jurnal Ekonomi Syariah Teori dan Terapan Vol. 5 No. 6 Juni 2018: 448-466; ANALISIS FAKTOR-FAKTOR YANG BERPENGARUH TERHADAP PROFITABILITAS PERUSAHAAN MANUFAKTUR YANG TERDAFTAR PADA ISSI TAHUN 2011-2015

hipotesis dengan uji t. Hasil dari pengolahan data, p-value dari PKP lebih besar dari a $(0.1223>0.05)$ sehingga $\mathrm{H}_{0}$ ditolak. Kesimpulan yang dapat diambil adalah Periode Konversi Persediaan tidak berpengaruh signifikan terhadap profitabilitas.

Periode Konversi Persediaan adalah lama waktu yang dibutuhkan perusahaan untuk mengkonversi bahan baku menjadi barang yang siap dijual. Hasil penelitian ini menunjukkan variabel Periode Konversi Kas berpengaruh negatif namun tidak signifikan terhadap profitabilitas, yang berarti semakin besar Periode Konversi Kas maka semakin kecil profitabilitas. Hasil ini mendukung penelitian Niken (2010) yang menyatakan bahwa PKP berpengaruh negatif namun tidak signifikan terhadap ROA.

Hal ini disebabkan karena semakin panjang waktu yang dibutuhkan perusahaan untuk menghabiskan persediaan maka semakin besar biaya yang harus dikeluarkan oleh manajemen perusahaan untuk biaya pemeliharaan. Dengan semakin tingginya biaya yang harus dikeluarkan, maka laba perusahaan akan semakin menurun. Sesuai dengan teori yang dinyatakan Brigham (2001) karena semakin lambat konversi persdiaan, maka akan semakin tinggi kebutuhan pendanaan eksternal, dan semkin besar biaya yang dibutuhkan.

Pengaruh Periode Pengumpulan Piutang Terhadap Profitabilitas Perusahaan Manufaktur pada Indeks Saham Syariah Indonesia.
Pengaruh Periode Pengumpulan Piutang terhadap profitabilitas secara parsial dapat dilihat melalui hasil pengujian hipotesis dengan uji t. Hasil dari pengolahan data, $p$-value dari Periode Pengumpulan Piutang lebih besar dari a (0.3282>0.05) sehingga $\mathrm{H}_{0}$ ditolak. Kesimpulan yang dapat diambil adalah Periode Pengumpulan Piutang tidak berpengaruh signifikan terhadap profitabilitas.

Periode Pengumpulan Piutangadalah lama waktu yang dibutuhkan perusahaan untuk menagih piutng dari pelanggan dengan pembelian nontunai.. Hasil penelitian ini menunjukkan variabel Periode Pengumpulan Piutangtidak berpengaruh signifikan terhadap profitabilitas. Hasil ini sesuai dengan penelitian Nurul Aini (2012) yang menyatakan bahwa tidak ada hubungan antara Periode Pengumpulan Piutang dengan profitabilitas.

$\mathrm{Hal}$ ini dikarenakan manajemen perusahaan manufaktur telah mampu melakukan pengelolaan piutang secara efektif sehubungan dengan pelunasan kredit, syarat kredit penjualan, serta penagihan piutang. Dimana baik daftar umur piutang akan mengalami distorsi. Distorsi adalah pemutarbalikan atau penyimpangan terhadap suatu aturan. teori, atau fakta (Aini, 2012:8)

Pengaruh Periode Penangguhan Utang Terhadap Profitabilitas Perusahaan Manufaktur pada Indeks Saham Syariah Indonesia.

Pengaruh Periode Penangguhan Utang terhadap profitabilitas secara parsial 
Qomaruddin, et al/ Jurnal Ekonomi Syariah Teori dan Terapan Vol. 5 No. 6 Juni 2018: 448-466; ANALISIS FAKTOR-FAKTOR YANG BERPENGARUH TERHADAP PROFITABILITAS PERUSAHAAN MANUFAKTUR YANG TERDAFTAR PADA ISSI TAHUN 2011-2015

dapat dilihat melalui hasil pengujian

hipotesis dengan uji t. Hasil dari

pengolahan data, p-value dari Periode Penangguhan Utanglebih kecil dari a (0.0007<0.05) sehingga $\mathrm{H}_{0}$ diterima.

Kesimpulan yang dapat diambil adalah Periode Penangguhan Utangberpengaruh negatif signifikan terhadap profitabilitas.

Periode Penangguhan

Utangmenunjukkan berapa lama waktu yang dibutuhkan perusahaan untuk melunasi utang dagangnya. Hasil penelitian ini menunjukkan variabel Periode Penangguhan Utangberpengaruh negatif signifikan terhadap profitabilitas. Hasil ini sesuai dengan penelitian Nurul Aini (2012) yang menyatakan bahwa Periode Penangguhan Utangberpengaruh negatif signifikan terhadap profitabilitas.

Hal ini dikarenakan adanya persyaratan kredit yang mengharuskan perusahaan membayar utangnya lebih cepat, jika tidak, maka mengakibatkan perusahaan harus mengeluarkan biaya lebih banyak untuk membayar bunga utang. Salah satu sumber pendanaan yang paling mudah dan paling umum adalah pinjaman bank. Sebagian besar pinjaman bank hanya memiliki waktu beberapa bulan. Dengan penambahan dana dari utang dagang, maka modal kerja akan meningkat sehingga dapat digunakan untuk menambah volume persediaan. Selain itu, keuntungan menggunakan utang dagang juga memiliki bunga yang lebih rendah dari utang jangka panjang. Jadi dapat disimpulkan bahwa Periode
Penangguhan Utangberpengaruh negatif signifikan terhadap profitabilitas.

Pengaruh Leverage Terhadap Profitabilitas Perusahaan Manufaktur pada Indeks Saham Syariah Indonesia.

Pengaruh Leverage terhadap profitabilitas secara parsial dapat dilihat melalui hasil pengujian hipotesis dengan uji t. Hasil dari pengolahan data, p-value dari Periode Penangguhan Utanglebih kecil dari a (0.19529>0.05) sehingga $\mathrm{H}_{0}$ ditolak. Kesimpulan yang dapat diambil adalah Leverage berpengaruh negatif tidak signifikan terhadap profitabilitas.

Leverage merupakan rasio yang digunakan untuk mengukur tingkat penggunaan utang terhadap total aset yang dimiliki. Semakin tinggi julah utang yang digunakan untuk membeli aset akan menyebabkan peningkatanbunga pinjaman yang ditanggung oleh perusahaan, sehingga akan memperkecil laba yang diperoleh.

. Hasil penelitian ini menunjukkan variabel Leverage berpengaruh negatif tidak signifikan terhadap profitabilitas. Hasil ini sesuai dengan penelitian Barus (2013) dan Hastuti (2010) yang menyatakan terdapat hubungan negatif antara leverage dan profitabilitas..

Pengaruh Debt to Equity Ratio Terhadap Profitabilitas Perusahaan Manufaktur pada Indeks Saham Syariah Indonesia.

Pengaruh Debt to Equity Ratio terhadap profitabilitas secara parsial dapat dilihat melalui hasil pengujian hipotesis dengan uji t. Hasil dari pengolahan data, p-value dari Debt to Equity Ratiolebih besar dari a (0.380>0.05) sehingga $\mathrm{H}_{0}$ ditolak. Kesimpulan yang dapat diambil adalah 
Qomaruddin, et al/ Jurnal Ekonomi Syariah Teori dan Terapan Vol. 5 No. 6 Juni 2018: 448-466; ANALISIS FAKTOR-FAKTOR YANG BERPENGARUH TERHADAP PROFITABILITAS PERUSAHAAN MANUFAKTUR YANG TERDAFTAR PADA ISSI TAHUN 2011-2015

Debt to Equity Ratio berpengaruh tidak signifikan terhadap profitabilitas.

Debt to Equity Ratiomenunjukkan perbandingan antara total utang perusahaan dengan total ekuitasnya atau dengan kata lain menunjukkan kemampuan perusahaan memmenuhi kebutuhan operasional dengan modal sendiri. Artinya, semakin banyak modal sendiri yang digunakan dalam kegiatan operasional perusahaan maka semakin kecil pula pinjaman dana dari pihak eksternal sehingga meminimalkan kewajiban dalam pembayaran bunga utang bagi perusahaan.

Hasil penelitian ini menunjukkan variabel Debt to Equity Ratio tidak berpengaruh signifikan terhadap profitabilitas. Hasil ini sesuai dengan penelitian Barus (2013) yang menyatakan bahwa Debt to Equity Ratio tidak berpengaruh signifikan terhadap profitabilitas.

Hal ini dikarenakan adanya persyaratan kredit yang mengharuskan perusahaan membayar utangnya lebih cepat, jika tidak, maka mengakibatkan perusahaan harus mengeluarkan biaya lebih banyak untuk membayar bunga utang. Salah satu sumber pendanaan yang paling mudah dan paling umum adalah pinjaman bank. Sebagian besar pinjaman bank hanya memiliki waktu beberapa bulan. Dengan penambahan dana dari utang dagang, maka modal kerja akan meningkat sehingga dapat digunakan untuk menambah volume persediaan. Selain itu, keuntungan menggunakan utang dagang juga memiliki bunga yang lebih rendah dari utang jangka panjang.

Jadi dapat disimpulkan bahwa Debt to Equity Ratioberpengaruh negatif signifikan terhadap profitabilitas.

\section{Pengaruh Current Ratio Terhadap Profitabilitas Perusahaan Manufaktur pada Indeks Saham Syariah Indonesia.}

Pengaruh Current Ratioterhadap profitabilitas secara parsial dapat dilihat melalui hasil pengujian hipotesis dengan uji t. Hasil dari pengolahan data, p-value dari Current Ratiolebih besar dari a (0.4013>0.05) sehingga $\mathrm{H}_{0}$ ditolak. Kesimpulan yang dapat diambil adalah Current Ratioberpengaruh tidak signifikan terhadap profitabilitas.

Current RatioRatiomenunjukkan perbandingan antara aset lancar perusahaan dengan utang jangka pendeknya.Hasil penelitian ini menunjukkan variabel Current Ratiotidak berpengaruh signifikan terhadap profitabilitas. Hasil ini sesuai dengan penelitian Niken (2010) dan Barus (2013) yang menyatakan bahwa Current Ratiotidak berpengaruh signifikan terhadap profitabilitas.

Hal ini disebabkan oleh faktor seperti adanya persediaan bahan baku dan bahan dalam proses yang tidak siap untuk dijual dan terdapat dalam .Sehingga besarnya komponen ini akan meningkatkan current asset tetapi tidak menghasilkan laba karena perusahan harus mengeluarkan biaya tambahan untuk memproses persediaan tersebut agar menjadi barang jadi yang siap jual 
Qomaruddin, et al/ Jurnal Ekonomi Syariah Teori dan Terapan Vol. 5 No. 6 Juni 2018: 448-466;

\section{ANALISIS FAKTOR-FAKTOR YANG BERPENGARUH TERHADAP PROFITABILITAS PERUSAHAAN MANUFAKTUR YANG TERDAFTAR PADA ISSI TAHUN 2011-2015}

DAFTAR PUSTAKA

Al-Quran dan Terjemahannya. 2002. Departemen Agama Republik Indonesia

Aditya, David. 2013. Manajemen Modal Kerja dan Profitabilitas Perusahaan Farmasi yang Terdaftar di Bursa Efek indonesia. Jurnalskripsitidakditerbitkan. MalangUniversitas Brawijaya.

Aini, Nurul. 2012.Pengaruh Manajemen Modal Kerja Terhadap Profitabilitas Perusahaan Food and Beverages di BEl Tahun 2007-2011. Jurnalskripsitidakditerbitkan. MalangUniversitas Brawijaya.

Anshori, Muslich dan Sri Iswati. 2009. Buku Ajar Metodologi Penelitian Kuantitatif. Surabaya: Pusat Penerbitan dan Percetakan Unair

Brigham, Houston. 2006. Dasar-Dasar Manajemen Keuangan. Buku 1 Edisi 10. Terjemahan Oleh Ali Akbar Yulianto dari Fundamental of Financial Management (2004). Jakarta: Salemba Empat.

Barus, Caroline. 2013.Faktor-Faktor yang Mempengaruhi Profitabilitas Perusahaan Manufaktur. Jurnalskripsitidakditerbitkan.Medan. Universitas Sumatera Utara.

Deloof, Marc. (2003)."Does Working Capital Management Affect Profitability of Belgian Firms?, Journal of Business Finance \& Accounting, 30(3) \& (4), April/Mei 2003. 573-588

Herdayanti, Yulia.2015.Pengaruh Manajemen Modal Kerja Terhadap Profitabilitas Perusahaan Ritel di ISSI Tahun 2012-2014

Hidayat, Mohammad. 2010. An Introduction to The Sharia Economic: Pengantar Ekonomi Islam. Jakarta: Zikrul Hakim (Anggota IKAPI).

Kasmir.2013. Analisis Laporan Kevangan. Edisi 1. Cetakan ke-6.Jakarta: Rajawali Press.

Santoso, Singgih. 2010. Latihan SPSS Statistik Parametric. Jakarta: Elex Media Komputindo

Sugiyono, 2005. Memahami Penelitian Kualitatif. Bandung. Alfabeta

Ghozali, Imam. 2006. Aplikasi Analisis Multivariate dengan SPSS.
Semarang: Badan Penerbit Universitas Diponegoro

Sujarweni, V. Wiratna. 2014. SPSS Untuk Penelitian. Yogyakarta: Pustaka Baru Press

Rochaety, Ety dkk. 2007. Metodologi Penelitian Bisnis dengan Aplikasi SPSS. Jakarta: Mitra Wacana Media.

Rosyid, Danang.2012.Analisis Pengaruh Manajemen Modal Kerja Terhadap Profitabilitas

PerusahaanManufakturl di BEI Tahun 2008-2010

Gujarati, Damodar. 2001. Ekonometrika Dasar. Jakarta: Erlangga

Lampost.co, Berita Online Lampung Post, diakses pada tanggal 30 Maret 2015.

Mogaka, Daniel danAmbrose Jagongo. 2013. Working Capital Management And Profitability:Evdence from Manufacturing and Contruction Firm Listed on Nairobi Securities Exchange, Kenya International Journal of Accounting and Taxation. Vol.1, No.1 December 2013.

Saghir, Hasmi, \& Hussain.2013.Working Capital Management And Profitability: Evidence From Pakistan Firm.Interdiciplinary Journal of Contemporary Research in Business.Vol. 3, No. 8 December 2011

Sudana, I Made. 2011. Manajemen Keuangan Perusahaan. Jakarta: Erlangga.

Surat Edaran Ketua Badan Pengawas Pasar Modal, tentang Pedoman Penyajian dan Pengungkapan Laporan Keuangan Emiten atau Perusahaan Publik

Tanjung, Akbar Susilo. 2013.Pengaruh Manajemen Modal Kerja Terhadap Kinerja Perusahaan Manufaktur di BEl Tahun 2011-2013. Malang: Universitas Brawijaya. Malang.

Website resmi Bursa Efek Indonesia www.idx.co.id 